Jurnal Psikologi Teori dan Terapan

2014, Vol. 5, No. 1, 30-37, ISSN: 2087-1708

\title{
Kebermaknaan Hidup Survivor Kanker Payudara Setelah Mastektomi
}

\author{
Ni Luh Handriani Pratiwi, dan Meita Santi Budiani ${ }^{1}$ \\ Program Studi Psikologi Universitas Negeri Surabaya
}

\begin{abstract}
Life meaning has an important role for one's life including for breast cancer survivors. Breast cancer is a disease which people, especially women, fear the most. The suffer they feel are not only when they get first diagnosis but also when they must accept that they will lose the most important part of their body through a mastectomy. It causes both physical and psychological impacts for the survivor. This study aimed to know the meaning of life of breast cancer survivor who had a mastectomy. The phenomenological qualitative approach was employed. Data collected using semi-structured intervies and analyzed using IPA (Interpretative Phenomenological Analysis). This study reveals five major themes. The first theme concerns about the response towards cancer diagnosis. The sample of this study shows the response such as denial, desperation, acception, even submission. The second theme is about the psychological impacts of breast cancerand mastectomy. The third theme is the positive and negative perception from the survivors towards the death. The negative respond was about a fear and the positive one was a readiness to face death. The fourth theme discusses the ways participants use to deal with the cancer. Then, the last theme is about the meaning of participants' life.
\end{abstract}

Keywords: Life meaning, breast cancer survivor, mastectomy

\begin{abstract}
Abstrak: Kebermaknaan hidup merupakan hal yang sangat berperan penting dalam kehidupan seseorang termasuk para penderita kanker payudara. Kanker payudara merupakan penyakit yang paling ditakuti oleh sebagain besar orang, khususnya perempuan. Penderitaan yang mereka tidak hanya saat menerima vonis tetapi mereka harus menerima bahwa salah satu bagian penting tubuh mereka akan lenyap lewat operasi mastektomi. Mastektomi adalah operasi pengangkatan payudara. Hal tersebut menimbulkan masalah fisik dan psikologis pada diri survivor. Penelitian ini bertujuan untuk mengetahui kebermakaan hidup survivor kanker payudara yang mengalami mastektomi. Penelitian ini menggunakan pendekatan kualitatif fenomenologis. Pengambilan data menggunakan teknik wawancara semi terstruktur. Data penelitian ini kemudian dianalisis menggunakan teknik IPA (Interpretative Phenomenological Analysis). Hasil penelitian menunjukkan lima tema besar. Tema pertama yakni respon terhadap vonis kanker. Partisipan pada penelitian ini menunjukkan respon penolakan, putus asa, dan menerima \& pasrah. Tema kedua yakni dampak psikologis vonis kanker payudara. Pada partisipan dampak yang ditimbulkan vonis kanker yaitu kecemasan. Tema ketiga persepsi terhadap kematian. Muncul dua sikap terhadap kematian pada partisipan yaitu negatif berupa rasa takut dan positif siap menghadapi kematian. Tema keempat cara menghadapi penyakit, dan tema kelima yaitu memaknai kehidupan yang terdiri sub tema yaitu arti kehidupan dan makna hidup.
\end{abstract}

Kata Kunci: Kebermaknaan hidup, survivor kanker payudara, mastektomi

Korespondensi tentang artikel ini dapat dialamatkan kepada Meita S. Budiani melalui email: ita_peha@yahoo.com 
Mendengar nama kanker saja membuat seseorang merasa merinding karena, penyakit ini begitu dekat dengan kematian. Kanker payudara (carsinoma mammae) adalah sekelompok sel yang tidak normal pada payudara yang terus menerus tumbuh berlipat ganda, dimana sel-sel itu kemudian membentuk benjolan pada payudara (American Cancer Society, 2012).

Tingginya angka kejadian kanker payudara mengakibatkan tidak sedikit pula penderita kanker payudara yang berujung pada kematian (Saryono \& Roischa, 2009). Data pasien yang dihimpun oleh RS Kanker Dharmais, Jakarta, menunjukkan, kanker payudara menempati urutan pertama penderita kanker di Indonesia. Tahun 2010 tangga teratas diambil alih oleh kanker payudara (37\%) (Femina online, 2012).

Hampir seluruh penyakit menimbulkan penderitaan, tetapi tidak semua penderitaan yang ditimbulkan penyakit dapat mendorong seseorang untuk mencari tahu makna hidupnya. Taylor (2003) menyatakan penyakit kronis seperti kanker dapat mendorong seseorang untuk mencari tahu makna hidupnya. Ada beberapa alasan kenapa penyakit kanker dapat mendorong seseorang untuk mencari tahu makna hidupnya, antara lain: kanker merupakan salah satu penyakit serius bahkan dalam beberapa kasus dapat menimbulkan kematian, pengobatan penyakit ini kadangkadang dapat menimbulkan perubahan permanen dari bentuk fisik seseorang, perubahan dalam hubungan, perubahan dalam ketertarikan dan orang lain mungkin akan melihat penderita kanker tersebut sebagai orang yang berbeda ("Meaning", 2007). Shock mental, takut, depresi, cemas, murung dan menolak, reaksi-reaksi itu akan muncul saat seseorang telah divonis kanker. Penyakit seperti kanker payudara merupakan salah satu penyakit yang dapat mendorong seseorang untuk mencari makna hidupnya, karena penyakit sejenis ini dapat menimbulkan banyak penderitaan bagi yang mengalaminya mulai dari ancaman kematian yang ditimbulkan serta dampak fisik, psikologis, sosial, dan ekonomi yang ditimbulkan oleh penyakit itu sendiri dan proses pengobatannya.

Makna hidup bagi penderita kanker payudara memberikan banyak pengaruh positif bagi penderitanya, dengan menemukan makna hidup penderita kanker payudara dapat menjalani semua proses pengobatannya dengan penuh semangat dan gairah yang nantinya akan berpengaruh terhadap kesembuhan penderita itu sendiri.

Makna hidup adalah hal-hal yang dianggap sangat penting dan berharga serta memberikan nilai khusus bagi seseorang sehingga layak dijadikan tujuan dalam kehidupan (Bastaman, 2007). Makna hidup terdapat dalam kehidupan itu sendiri, dan dapat ditemukan dalam setiap keadaan, baik menyenangkan maupun tidak menyenangkan, dalam keadaan bahagia ataupun penderitaan (Bastaman, 2007) karena kehidupan manusia di dunia tidak selamanya dipenuhi dengan kesenangan namun juga dengan penderitaan (Frankl dalam Bastaman, 1996).

Dari serangkaian paparan diatas, munculah ketertarikan melakukan penelitian tentang kebermaknaan hidup pada survivor kanker payudara yang mengalami mastektomi.

\section{Metode}

Penelitian ini adalah penelitian kualitatif. Proses dan makna (perspektif partisipan) lebih ditonjolkan dalam penelitian ini dengan pendekatan fenomenologis. yang bertujuan untuk memperoleh jawaban atau informasi mendalam tentang kebermaknaan hidup pada survivor kanker payudara dan apa yang menjadi makna hidup survivor kanker payudara. Metode pengumpulan data yang pertama digunakan dalam penelitian ini adalah wawancara mendalam (indept interview). Dalam hal ini metode wawancara mendalam yang dilakukan dengan adanya pertanyaan yang telah dipersiapkan sebelumnya (Moleong, 2005:186). Data dianalisis menggunakan 
Interpretative Phenomenologis Analysis (IPA). Pelaksaan teknik pemeriksaan keabsahan data penelitian ini dilakukan triangulasi dengan triangulasi penyidik. Adapun triangulasi penyidik yaitu melibatkan pengamat diluar peneliti yang turut memeriksa hasil pengamatan data dalam penelitian ini adalah dosen pembimbing.

\section{Hasil}

Hasil penelitian ini berhasil mengindentifikasi 5 (lima) super ordinat tema atau tema besar yakni: respon terhadap vonis kanker, dampak psikologis saat vonis kanker, persepsi terhadap kematian, cara menghadapi penyakit, dan memaknai kehidupan.

\section{Respon Terhadap Vonis Kanker}

\section{a. Sub Tema: Penolakan (Denial)}

Respon penolakan atau denial dalam menghadapi vonis kanker adalah menghindari kenyataan bahwa dirinya menderita kanker.

"[...] Saya punya perasaan nggak terima waktu itu, kok saya di beri penyakit seperti ini." (P1)

"[..] Ya cuman pernah kok aku dikasih penyakit seperti ini. Saya kok punya penyakit seperti ini. Padahal saya nggak pernah berbuat apa-apa. Dosa saya apa kok saya begini" (P2)

"[...] Pikiran saya waktu itu kenapa saya, apa salah saya, berapa lama hidup saya." (P4)

\section{b. Sub Tema: Putus Asa (Hopeless)}

Menerima kenyataan bahwa dirinya menderita kanker membuat sebagian partisipan merasakan suatu keputusasaan. Mereka menolak kenyataan bahwa ia tidak akan pulih lagi.

“[...] Ya rasanya nggak ada semangat sama sekali, putus asa, nggak ada rasa semangat sama sekali (ekspresi wajah menahan tangis dan sedih)". (P1)

“[...] Enak'an mati yo." (P2)

"[...] Saya sedih, hidup saya berapa lama lagi." (P4)

\section{c. Sub Tema: Menerima Dan Pasrah}

Pada akhirnya mereka mampu menerima keadaan dan pasrah atas apa yang menimpanya.

"Kita harus ikhlas. Ini suatu musibah. Kita terima dengan ikhlas.” (P1)

"Ya menerima mbak. Udah dikasih ujian diterima aja. Dijalani aja. Semua yang diatas yang ngatur." (P2)

"[...] Datar saja. Biasa. Karena penyakit itu siapa pun bisa dapet."(P3)

"Tapi sekarang sudah ikhlas. Karena segala sesuatu jika bisa diterima dengan ikhlas itu lebih indah." (P4)

\section{Dampak Psikologis Vonis Kanker}

Pada penelitian ini muncul dampak psikologis vonis kanker yaitu berupa kecemasan.

\section{Sub Tema : Kecemasan}

Kecemasan merupakan bentuk perasaan takut serta kekhawatiran yang lebih. Kondisi tersebut muncul sebagai dampak psikologis saat menerima vonis kanker.

“[...] ya antara gini gak enak, gini nggak enak. Nggak nyaman. Serba salah. Nggak tenang. Tidur nggak enak.” (P1)

"Di rumah sakit juga nggak bisa tenang Pikiran kemana-mana. Takut gini-gini.” (P2)

\section{Sikap Terhadap Kematian}

Pada penelitian ini memunculkan dua sikap terhadap kematian yaitu negatif berupa rasa takut dan positif siap dalam menghadapi kematian.

\section{a. Sub Tema: Takut Mengahadpi Kematian}

Perasaan takut menghadapi kematian menimbulkan pikiran tidak tenang ketika membanyangkan kematian. Seseorang seperti ini merasa masih memiliki tanggungan/ beban yang belum terselesaikan dalam hidupnya. 
"Namanya ibu ya, masih punya anak kecil-kecil. Takut mati, takut apa. Oh ya saya kok sakit gini. Berarti umur saya sudah dekat." (P2)

\section{b. Sub Tema: Siap Mengahapi Kematian}

Bagi seorang yang lain kematian merupakan sesuatu yang harus diterima dengan ikhlas dan dipersiapkan.

"Kalau Allah menghendaki saya sudah ikhlas, memang sudah takdirnya." (P1)

"[...] Jadi InsyaAllah saya sudah siapkan semua." (P3)

\section{Cara Menghadapi Penyakit}

Menderita penyakit yang banyak ditakuti oleh sebagian besar orang merupakan hal yang tidak mudah. Setiap partisipan memiliki pandangan yang berbeda dalam menghadapi penyakit tersebut. Cara pandang tersebut tentunya mempengaruhi bagaimana cara menghadapi penyakit yang dialaminya.

\section{a. Sub Tema: Dukungan Sosial}

Dukungan sosial merupakan peranan penting dalam membantu pasien untuk membangkitkan semangat hidupnya dan pasien merasa dirinya berarti.

"Dukungan dari suami dan anak ya di suruh cepet operasi.” (P1)

"Mau operasi itu seh agak tenang dikasih doa sama anak-anak.” (P2)

"[...] Secara psikis kita jadi nyaman kan ya diajak ngomong, dikasih jus, bukan jusnya tapi perhatiannya" (P3)

"Tapi itu tidak lepas juga dukungan dan perhatian dan rasa kasih sayang yang besar. Semangat dan motivasi yang besar dari keluarga saya, anak-anak saya, dan suami saya. Mereka betul-betul ikut merasakan apa yang saya rasakan.” (P4)

\section{b. Sub Tema :Perilaku Coping}

Saat menghadapi masalah atau tekanan seseorang akan melakukan usaha untuk melindungi diri dari masalah atau tekanan-tekanan yang dihadapinya.
Usaha yang dilakukan disebut dengan perilaku coping.

"[...] Suami saya ngajak sholat saya supaya tenang. Jam 3 bangun sholat malem (malam) terus sholat di masjid sama Bapak.” (P1)

"[...] Mau operasi itu seh agak tenang dikasih doa sama anak-anak.” (P2)

“[...] Bukan berarti hidup itu nggak pernah stres lho ya. Pastilah datang lah sesekali. Tapi saya usahakan kalau datang, oke apa yang harus saya lakukan, saya harus ngapain. Kesukaan saya komputer, ya sudah saya komputer atau bercocok tanam udah." (P3)

"[...] Dengan cara apa ya, dengan cara berobat yang benar, pengobatan yang benar, menjaga hati. Kita kan nggak boleh negatif thinking (berburuk sangka). Semua kita harus ambil hikmah.” (P4)

\section{c. Sub Tema : Reaching Out}

Kanker payudara merupakan peristiwa hidup yang penuh tantangan dan perjuangan. Peristiwa tersebut memunculkan dampak fisik dan psikis bagi penderitanya. Tidak hanya pada diri pasiennya tapi juga keluarga. Berada dalam keadaan seperti itu para partisipan mampu bangkit dan bertahan dari masalah yang ada. Hal tersebut karena mereka dapat mengembangkan kemampuan resiliensinya yaitu reaching out.

“[...] Saya pikir-pikir semua dari yang diatas, kita ya harus kembali ke yang diatas” (P1)

"Ya menerima mbak. Udah dikasih ujian diterima aja. Dijalani aja. Semua yang diatas yang ngatur.” (P2)

"Saya bukan bersyukur diberi penyakit ya. Bersyukur diberi itu sehingga saya bisa lebih tawakal, lebih sabar, lebih tau kebesaran Allah. Mungkin, dengan saya sakit dosa-dosa saya terampuni, terkurangi gitu” (P3)

“[...] Allah memberi cobaan ini karena Allah memberi hal yang indah lain yang kita nggak tau” (P4)

\section{Memaknai Kehidupan}

Kehidupan yang dijalani manusia tidak lepas dari sesuatu yang menyenang- 
kan dan tidak menyenangkan. Kehidupan yang seperti itu juga terjadi dalam hidup partisipan. Memaknai kehidupan agar mampu menghadapi penyakit membuat partisipan memahami arti kehidupan dan makna hidupnya.

\section{Sub Tema: Arti Kehidupan}

Pasca vonis kanker banyak hikmah yang diambil oleh partisipan. Menerima kenyataan bahwa dirinya mengidap penyakit kanker membuat mereka memahami arti kehidupan.

\footnotetext{
"Saya itu nggak terlalu muluk-muluk, apa adanya. Dibawah kita masih ada. Banyak bersyukur" (P1)

"Seperti mimpi. Ya kan. Dulu seperti ini, terus begini. ”(P2)

"Kehidupan itu sesusatu yang menarik yang harus kita jalanin berbagai apa ya, kiat-kiat yang kalau kita bertemu yang manis nikmati yang manis, kalau bertemu yang pahit usahakan menjadi manis. Hidup itu indah. Jadi jangan dibuat nggak indah karena ada masalah kalau nggak ada masalah itu namanya nggak hidup" (P3)

"Saya ingin mengalami kehidupan yang bahagia dunia dan akhirat. Saya ingin berbagi, melakukan yang terbaik untuk semua orang" (P4)
}

\section{Sub Tema: Makna Hidup}

Setiap orang ingin menjadi seseorang yang berguna dan berharga untuk keluarga, lingkungan/ masyarakat, dan dirinya sendirinya hal tersebut menunjukkan bahwa adanya makna hidup pada diri seseorang.

“[...] Saya pengen membesarkan anak-anak sampai lulus. Menikahkan anak-anak. Diberi umur panjang. Ya saya pengen melihat anakanak menikah sampai punya anak. Ya itu yang utama, sudah tua.” (P1)

"Pengennya cepet sembuh dan cepet-cepet kerja lagi seperti dulu. Moga-moga setelah penelitian sembuh total" (P2)

"[...] saya pengen bisa berbuat untuk sesama. Apa saja yang bisa saya lakukan” (P3)
"Target saya ingin berbuat baik untuk semua orang. Terutama kepada keluarga saya. saya ingin berbuat baik untuk keluarga saya dan semua orang. Itu saja” (P4)

\section{Pembahasan}

Penelitian ini menitik beratkan pada kebermaknaan hidup survivor kanker payudara yang mengalami mastektomi dan peneliti mengidentifikasi lima tema mengenai kebermaknaan hidup survivor kanker payudara yang mengalami mastektomi yaitu: respon terhadap vonis kanker, dampak psikologis saat vonis kanker, persepsi terhadap kematian, cara menghadapi penyakit, dan memaknai kehidupan yang selanjutnya akan dibahas masing-masing tema secra rinci yang telah diidentifikasikan berdasarkan tujuan penelitian.

\section{Respon Terhadap Vonis Kanker}

Pada penelitian ini berhasil mengungkap respon yang terjadi saat vonis, diantaranya penolakan (denial) yang merupakan dimana masa partisipan menolak bahwa dirinya mengidap penyakit kanker payudara, kedua putus asa (hopeless) yang dimana partisipan merasakan masa-masa putus asa saat terdiagnosa kanker payudara, dan terakhir yaitu menerima dan pasrah yang pada akhirnya partisipan menerima dan pasrah bahwa dirinya tervonis kanker payudara.

Respon pertama adalah penolakan (denial) pada masa ini partisipan merasa tidak yakin bahwa dirinya menderita kanker payudara. Kubler Roos menyatakan (dalam Bishop, 1994, h. 273-274) bahwa terdapat lima tahapan yang terjadi pada pasien yang menghadapi penyakit kronis. Tahapan tersebut antara lain, denial, marah, tawar-menawar, depresi dan penerimaan.

Respon kedua yang terjadi adalah putus asa (hopeless). Respon putus asa dirasa sudah nasibnya menderita kanker 
yang berarti sudah tidak ada harapan lagi, menolak kenyataan bahwa ia tidak akan pulih lagi, dan mampu bertahan menghadapi penyakitnya. Menurut Crary, dkk (2010, h.37) ia menjelaskan, penderita kanker payudara akan mengalami respon emosi yang negatif. Emosi negatif yang berhubungan dengan penyakit kanker antara lain anxiety (takut dan ketakutan), marah (frustrasi dan kegusaran), dan depresi (rasa bersalah dan putus asa). Respon ketiga yang terjadi pada masa ini adalah ketiga partisipan dapat menerima kondisi yang ia alami. Mereka pada akhirnya memilih untuk menerima dan pasrah terhadap penyakit yang berada dalam dirinya. Ketiga partisipan berpendapat sama bahwa kejadian ini harus menerima dengan ikhlas. Perasaan ikhlas ini yang membuat ketiga mampu menerima penyakit yang sedang diderita.

\section{Dampak Psikologis Vonis Kanker}

Menyadari bahwa di dalam tubuhnya terdapat sel-sel kanker yang sedang berkembang juga memuculkan dampak psikologis pada diri penderita kanker payudara. Dampak psikologis yang muncul dari hasil penelitian ini adalah kecemasan. Kecemasan terjadi hanya pada partispan pertama dan kedua. Bentuk dari kecemasan adalah perasaan gelisah, takut, atau khawatir yang merupakan manifestasi dari faktor psikologis dan fisiologis. Diungkapkan dalam studi yang dilakukan oleh Sandin dan kawan-kawan (de Groot, 2002) menjelaskan bahwa para wanita, terutama pada kasus kanker payudara lebih memiliki pengalaman dan perasaan takut serta kekhawatiran yang lebih besar. Respon tersebut terjadi setelah diagnosis (Bishop,1994,h.349). Seperti yang diungkapkan Rosyidi (2009) penderita kanker akan merasa cemas dengan penyakitnya, dengan tipisnya harapan kesembuhan, dengan besarnya biaya yang harus dikeluarkan dan berbagai hal yang mencemaskan lainnya.

\section{Persepsi Terhadap Kematian}

Penyakit kanker merupakan salah satu penyakit kronis yang menyebabkan kematian. Sehingga ketika orang mendengarnya mereka memunculkan persepi terhadap kematian. Ketika seseorang menghadapi kematian, ada yang menghadapinya secara positif namun tidak jarang pula yang menghadapinya secara negatif. Bahwa orang yang hidup pasti akan mengalami mati. Sebagai manusia kita tidak tahu kapan dan dimana kematian itu akan datang. Ketika membicarakan tentang persepsi terhadap kematian pada penelitian ini, berhasil mengidentifikasi bagaimana perasaan yang mucul mengenai kematian terdapat dua macam yaitu negatif dan positif. Perasaan takut menghadapi kematian merupakan persepsi negatif yang muncul pada partisipan kedua. Perasaan takut terhadap kematian dirasakan partisipan kedua karena ia sebagai ibu masih mempunyai tanggungan untuk membesarkan anak-anaknya yang masih kecil. Hal ini sesuai dengan teori dari Aiken (1994) yang menyatakan bahwa kecemasan atau ketakutan akan kematian menimbulkan sejumlah pemikiran, salah satunya adalah perpisahan dengan orang yang disayangi, dalam hal ini suami dan anak-anak. Sebaliknya mereka yang mempunyai persepsi postif terhadap kematian ialah seseorang yang siap dalam menghadapi kematian. Fase penerimaan menjelang kematian milik Kubler Ross (dalam Santrock 1995) menyatakan, penerimaan (acceptance) merupakan fase kelima menjelang kematian, dimana seseorang mengembangkan rasa damai, menerima takdir, dan dalam beberapa hal ingin ditinggal sendiri.

\section{Cara Menghadapi Penyakit}

Penelitian ini memunculkan tiga hal bagaimana cara partisipan menghadapi penyakit kanker payudara yaitu dengan 
dukungan sosial, perilaku coping, dan reaaching out.

Dukungan sosial adalah kenyamanan secara fisik dan psikologis yang diberikan oleh teman atau anggota keluarga (Baron dan Byrne, 2005). Disinilah peran keluarga menjadi penting pada seseorang yang menderita penyakit kronis karena disaat seseorang sakit secara fisik dan terganggu psikis, sulit diharapkan untuk dapat menerima keadaan. Peran suami, orangtua, dan anak dalam memberikan ketenangan sangat dibutuhkan. Friedman (dalam Anggraeni dan Ekowati, 2010) mengemukakan bahwa perhatian dari suami atau istri termasuk kelompok dukungan internal yang sangat membantu pemulihan kesehatan bagi pasangannya yang dirawat. Sumber dari dukungan sosial adalah orang lain yang berinteraksi dengan individu sehingga individu dapat merasakan kenyamanan fisik dan psikologis. Orang lain ini terdiri dari pasangan hidup, orangtua, saudara, anak, kerabat, teman, rekankerja, serta staf medis yang merawat pasien (Niven,2002).

Coping dalam menghadapi penyakit dilakukan partisipan untuk mengurasi perasaan tidak tenang, stres, dan cemas. Coping yang dilakukan sangat bervariasi antara partisipan satu dengan partisipan lainnya. Seseorang akan memberikan penilaian yang berbeda terhadap situasi atau permasalahan tertentu. Koping dibutuhkan pasien sebagai upaya menghadapi ancaman fisik dan psikososial (Budi, 1998). Coping yang berhasil adalah yang melibatkan pengendalian kontrol (regulatory control) - proses-proses yang memungkinkan individu untuk mengarahkan aktivitasnya diberbagai waktu dan situasi (Baron dan Byrne, 2005).

Reaching Out merupakan salah satu tujuh kemampuan yang membentuk resiliensi, reseliensi merupakan kemampuan seseorang untuk bertahan, bangkit, dan menyesuaikan dengan kondisi yang sulit (Reivich dan Shatte, 2002). Reaching Out adalah kemampuan individu meraih aspek positif atau mengambil hikmah dari kehidupan setelah kemalangan yang menimpa. Kemalangan dalam hal ini adalah menderita kanker payudara. Kemampuan keempat partisipan untuk bangkit dan menyesuaikan kondisi terhadap penyakit yang dideritanya membuat keempatnya dapat mengambil hikmah dari kemalangan atau musibah kanker payudara yang terjadi padanya.

\section{Memaknai Hidup}

Survivor merupakan sebutan bagi seseorang dengan kanker. Dalam penelitian ini partisipan adalah seorang survivor kanker payudara. Pada awalnya mereka menolak akan kehandiran kanker payudara dalam dirinya. Kemudian mereka merasakan bagaimana rasanya menjalani serangkaian pengobatan yang menyita tenaga fisik maupun psikis, dan kehilangan payudara. Semua hal tersebut berhasil dilalui oleh keempat partisipan dalam menghadapi penyakit kanker payudara sebagai sebuah ujian atau cobaan. Pada akhirnya mereka menjadi lebih mengerti apa arti kehidupan dan lebih memaknai hidup yang mereka miliki. Sejalan dengan pendapat Bastaman (1996) dimana partisipan mampu merubah kondisi penghayatan dirinya dari penghayatan hidup tidak bermakna (meaningless) menjadi bermakna (meaningful).

\section{Simpulan}

Berdasarkan hasil penelitian yang dilakukan peneliti mengenai kebermaknaan hidup pada survivor kanker payudara yang mengalami mastektomi didapatkan kesimpulan sebagai berikut. Pertama, terdapat tiga macam respon terhadap vonis kanker pada partisipan yaitu penolakan (denial), putus asa (hopeless), dan menerima dan pasrah. Sedangkan dampak psikologis yang terjadi pada partisipan setelah mengetahui vonis kanker payudara adalah kecemasan dimana partisipan 
merasa selalu cemas, was-was, khawatir setiap saat tanpa adanya alasan yang jelas.Persepsi terhadap kematian dari partisipan dapat digolongkan menjadi dua persepsi yaitu negatif dan positif.

Dukungan sosial, Coping, dan Reaching Out merupakan tiga cara yang membuat parisipan mampu menghadapi penyakit. Memaknai kehidupan merupakan bagian dimana partisipan menjelaskan arti kehidupan dan makna hidup dalam kehidupan ini. Bagaimana mereka memahami sebuah kehidupan dan memaknai hidup yang mereka jalani.

\section{Daftar Pustaka}

Aiken, L. R. (1994). Death and breavement. Boston: Allyn and Bacon.

Baron, Robert A., \& Byrne, Donn. (2005) Psikologi Sosial Jilid 2 (edisi kesepuluh). Alih bahasa Ratna Djuwita, Melania Meitty Parman, Dyah Yasmina, \& Lita P. Lunanta. Jakarta: Erlangga

Bastaman, H. D. (1996). Meraih Hidup Bermakna. Kisah Pribadi dengan Pengalaman Tragis. Jakarta : Paramadina

Bastaman, H. D. (2007). Logoterapi. Psikologi untuk Menemukan Makna Hidup dan Meraih Hidup Bermakna. Jakarta : PT. RajaGrafindo Persada

Bishop, G.D. (1994). Health Psychology integrating Mind and Body. Singapore: Allyn and Bacon.

Breast Cancer. (2012). American Cancer Society [online] diakses pada tanggal 28 Desember 2012 dari: http://www.cancer.org/Cancer/BreastCa ncer

Keliat, Budi Anna. (1998). Gangguan Koping, Citra Tubuh, dan Seksual Pada Klien Kanker. Jakarta : EGC.
Niven, N., (2002). Psikologi Kesehatan. Jakarta: Penerbit Buku Kedokteran EGC.

Reivich, K. \& Shatte, A. (2002). The Resilience Factor: 7 Essential Skills for Overcoming Life's Inevitable Obstacles. New York: Broadway Books.

Santrock, J. W. (2002). Life-Span development (edisi kelima) : Perkembangan masa hidup. Alih bahasa: Achmad Chusairi \& Juda Damanik. Jakarta : Erlangga

Saryono dan Roischa D.P. (2009). Perawatan Payudara. Yogyakarta: Mitra Cendikia Press.

Taylor, S.E., (2003). Health Psychology. University of California, Los Angeles: Mc Graw Hill.

Zatnika, Iis (2011, 12 Desember). Segera Biopsi, Jangan Biarkan Kanker Payudara Menyebar. Pusat Data \& Informasi PERSI [on-line] Diakses pada tanggal 4 Agustus 2013 dari http://www.pdpersi.co.id/content/news. php 